\title{
Papers
}

\section{Layer or top-up? Why European hotel investors should include revenue management in their investment decisions}

Received (in revised form): 19 August 2008

\section{Lara Sarheim}

is an associate with HVS's London office. She joined HVS in 2007, having had six years of operational and managerial hotel industry experience in the USA. Before joining HVS, Lara held the position of Director of Revenue Management with Mandarin Oriental Hotel Group, at their flagship property in New York. Lara holds a Bachelor of Science in International Hospitality Management from the Ecole hôtelière de Lausanne, in Switzerland. Since joining HVS, Lara has worked on feasibility and valuation studies across Europe.

\begin{abstract}
Revenue management is an increasingly important tool for hotels to achieve the highest RevPAR (revenue per available room) possible. As RevPAR is the barometer for hotel performance, it follows that an understanding of revenue management strategies and techniques would help investors to have a more thorough understanding of the dynamics behind a hotel's RevPAR, and therefore would enable them to make wiser and more knowledgeable investment decisions in local market conditions. This paper explores the relationship among the different revenue management strategies applied to different types of hotels (limited, focused and full service) and the resulting variations in RevPAR performance specific to the local competitive market and its conditions.
\end{abstract}

\section{Keywords:}

revenue management, RevPAR, hotel investments, yield management, hotel development

Journal of Retail and Leisure Property (2008) 7, 265-273. doi:10.1057/rlp.2008.18; published online 8 October 2008

Lara Sarheim HVS Global Hospitality Services 7-10 Chandos Street Cavendish Square London W1G 9DQ, UK Tel: +442078787765 (direct) Fax: +442078787799 E-mail: Isarheim@hvs.com Web: www.hvs.com

\section{INTRODUCTION}

Revenue management has become an increasingly important topic in the hotel industry in recent years, and has in many ways gone from being a primarily property-level discipline to being an important tool for hotel investors in terms of asset management. Although property-level revenue managers handle the day-to-day revenue optimisation process, skilled asset managers seek to cooperate closely with property-level revenue and 
strategic management to ensure that asset value is optimised over the planned holding period of the asset. This paper seeks to explore the importance of revenue management to hotel investors from the moment an investment opportunity is identified. The general real estate dogma is 'location, location, location'; the fast-paced evolution of the hotel industry justifies the adaptation of this dogma to read: 'the right asset for the right location'. The author considers that a strengthened understanding of revenue management principles by hotel investors will permit them to make better investment decisions. This paper explores how data from a mature and well-segmented hotel industry (the USA) could be helpful when it comes to making good investment decisions in the European hotel market.

A review of a variety of markets in the USA that are well segmented (that is, consist of a variety of hotel products that seek to meet the specific purchasing requirements of a particular customer group) indicates that in many cases, focused-service and limited-service brands may outperform full-service products from the same brand family in terms of (revenue per available room) RevPAR. This is particularly evident in those cases where the full-service brands achieve occupancy percentages in the mid-50s to low 60 s per cent. Although these data do not suggest that all focusedservice and limited-service hotels will outperform their full-service counterparts, they do permit an interesting observation that will be examined in this paper. This paper will try to identify the pertinent factors that impact market performance in different segments, as well as the implications that the knowledge from the US market may have for hotel investment in Europe.

When a market is running at near capacity, a traditional strategy is to increase rates as much as the market will bear and sell the last few rooms at a premium. The thought behind this strategy is that the fewer the rooms available in the market, the higher the price a hotel can charge as the rooms are sold. In this respect, being the 'last to sell out' is a favourable position, as it permits the sale of the remaining inventory at the highest possible price. This strategy is, however, dependent on the existence of a strong occupancy base on the date in question. In markets where yearly occupancy averages around 65 per cent or less, and where there are few 'sell-out' dates, hotels have less of an opportunity to drive their rates. It is in these markets that there is opportunity for the RevPAR performance of limited-service and focusedservice hotels to exceed that of their full-service counterparts.

\section{YIELD STRATEGY - LAYERING DEMAND}

The core principle of yield or revenue management is to 'sell the right room, at the right price, to the right customer at the right time' in order to optimise RevPAR. This does not always mean selling a room at the highest price and achieving the highest average rate, as RevPAR is the product of occupancy and average rate.

The above phrase encompasses the four considerations a revenue manager must deal with daily in order to yield a hotel effectively: product, price, customer and time. The most effective way to approach this is to segment the customer (demand) base into different types of demand; each type of demand will have different room needs, rate tolerance and lead time before booking (booking window). 
Table I: Layers of demand by length of booking window

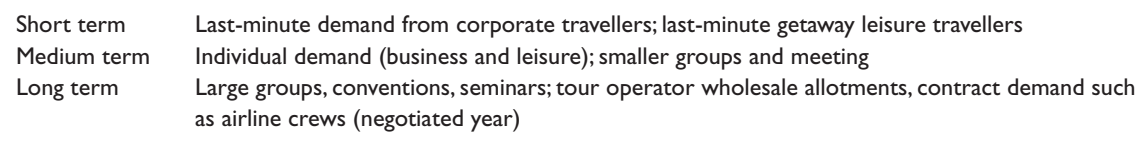

Traditionally, a hotel will look to fill rooms with a base tier of demand, and will then manage each layer of demand with different rates and booking restrictions. One way of looking at the different types of demand is by booking window, or how far in advance a customer reserves a room (Table 1$)$.

Since room nights are in fact a perishable product, as time goes by and the arrival date approaches it becomes increasingly urgent for the hotel to sell its rooms in order to optimise RevPAR. The specific segmentation will vary from hotel to hotel, as each property is unique within its own micromarket; however, the intention of this table is to show general trends.

The traditional held yield strategy is to fill a percentage of the inventory with groups (contract demand, allotments) at discounted rates, thereby securing a base layer of occupancy. As the date of arrival approaches and base occupancy augments, the hotel will steadily increase rates too, because rooms in lower categories will sell out first, leaving higher-category rooms at higher rates. In the week before the arrival date, rates are increased continuously with 'last minute' higher-rated business. The increase in rate is necessary to balance out the previously sold group or contract discounted rates. This is an effective strategy in busy markets where there is enough demand for individual hotels to keep pushing rates until the day of arrival. Hotels often encounter a situation in which there is not enough compression in the market to fill these last few rooms at full rate. In these cases, hotels may not yet have reached their occupancy target and may still have rooms left to sell. The only option then is to discount rates in an attempt to stimulate demand to sell the last few rooms before unsold nights 'expire' as business opportunities. Unfortunately, this nullifies the hotel's potential to balance out previously discounted rooms with rooms at full rates, thus leaving behind the potential to increase its RevPAR. The fine line between gaining occupancy and losing rate can change RevPAR results quite significantly.

\section{YIELD STRATEGY - TOP-UP DEMAND}

The reverse approach would be not to accept any blocks of rooms at lower rates farther away in time, and for a hotel to sell the majority of its inventory to transient guests at prices with less overall variance. This would appear to be the riskier approach, as generally it is reassuring for hotel managers to see 'rooms on the books' for months ahead, and it is certainly not possible in every situation. As the date of arrival approaches and rooms fill with transient reservations, if occupancy is still lagging, a hotel following this strategy can afford to discount the last few rooms in order to maximise occupancy, since it has not already discounted blocks of inventory with groups or allotments. In effect, the hotel is 'topping up' with lower-rated demand and on an already strong-rated demand base. 
The emergence of third-party internet distributors and the gradual move by transient customers towards shorter booking windows have greatly aided this particular revenue strategy. Hotels following this strategy can do so in the knowledge that they can reach out to a relatively large audience at the last minute, and combining this with attractive rates can thus produce strong occupancy year-round. This strategy is reliant on a very strong and wide-reaching distribution system and booking engine.

The 'top-up' revenue management strategy is most effective in smaller hotels that rely very much on transient demand, such demand is becoming increasingly last minute.

\section{LIMITED-SERVICE VS FOCUSED-SERVICE VS FULL-SERVICE HOTELS}

Tables 2 and 3 show sample data from two gateway cities in the USA. For the purposes of this study, a gateway city is defined as a city with an international airport. The author notes that these markets represent samples from the USA chosen for illustrative purposes. The overall study includes a much broader sample, which has been reviewed to support the analysis presented in this paper.

Table 2: Sample data — gateway city, mid-western USA (US\$)

\begin{tabular}{|c|c|c|c|c|c|c|}
\hline \multirow[t]{2}{*}{ Segment } & \multicolumn{2}{|c|}{ Limited service } & \multicolumn{2}{|c|}{ Focused service } & \multicolumn{2}{|c|}{ Full service } \\
\hline & Range & Average & Range & Average & Range & Average \\
\hline Number of rooms & $64-233$ & 125 & $87-357$ & 245 & $188-928$ & 574 \\
\hline Average rate & $79-159$ & 96 & $84-197$ & 138 & $108-239$ & 158 \\
\hline Occupancy (\%) & $62-81$ & 70 & $68-80$ & 75 & $55-80$ & 69 \\
\hline RevPAR & $50-129$ & 68 & $57-156$ & 104 & $45-180$ & 112 \\
\hline Largest meeting space $\left(\mathrm{m}^{2}\right)$ & \multicolumn{2}{|l|}{150} & \multicolumn{2}{|l|}{260} & \multicolumn{2}{|c|}{3,700} \\
\hline Location & \multicolumn{2}{|l|}{ Suburban } & \multicolumn{2}{|c|}{ Suburban/city centre } & \multicolumn{2}{|c|}{ City centre } \\
\hline F\&B facilities & \multicolumn{2}{|c|}{ Breakfast only } & \multicolumn{2}{|c|}{ Full F\&B services } & \multicolumn{2}{|c|}{ Full F\&B services } \\
\hline Condition & \multicolumn{2}{|c|}{-} & \multicolumn{2}{|c|}{$\begin{array}{l}\text { Recent construction } \\
\text { or conversion }\end{array}$} & \multicolumn{2}{|c|}{ Recent or planned renovation } \\
\hline
\end{tabular}

Source: HVS Research

Table 3: Sample data — gateway city, southern USA (US\$)

\begin{tabular}{|c|c|c|c|c|c|c|}
\hline \multirow[t]{2}{*}{ Segment } & \multicolumn{2}{|c|}{ Limited service } & \multicolumn{2}{|c|}{ Focused service } & \multicolumn{2}{|c|}{ Full service } \\
\hline & Range & Average & Range & Average & Range & Average \\
\hline Number of rooms & $131-159$ & 145 & $90-318$ & 177 & $236-601$ & 382 \\
\hline Average rate & $109-113$ & 111 & $108-170$ & 129 & $134-256$ & 170 \\
\hline Occupancy (\%) & $80-86$ & 83 & $69-84$ & 77 & $52-86$ & 72 \\
\hline RevPAR & $88-97$ & 92 & $81-126$ & 99 & $94-187$ & 120 \\
\hline Largest meeting space $\left(\mathrm{m}^{2}\right)$ & \multicolumn{2}{|l|}{30} & \multicolumn{2}{|l|}{70} & \multicolumn{2}{|c|}{1,900} \\
\hline Location & \multicolumn{2}{|l|}{ Suburban } & \multicolumn{2}{|c|}{ Urban } & \multicolumn{2}{|c|}{ City centre } \\
\hline F\&B facilities & \multicolumn{2}{|l|}{ Breakfast only } & \multicolumn{2}{|c|}{ Breakfast only } & \multicolumn{2}{|c|}{ Full F\&B services } \\
\hline Condition & \multicolumn{2}{|l|}{-} & \multicolumn{2}{|c|}{$\begin{array}{l}\text { Recent construction or } \\
\text { conversion }\end{array}$} & \multicolumn{2}{|c|}{ Recent renovation } \\
\hline
\end{tabular}

Source: HVS Research 
In these two samples, the three hotel segments behave according to expectation, with the full-service segment exceeding both the limitedservice and the focused-service hotels, in terms of both average rate and RevPAR.

Table 2 shows that RevPAR among full-service hotels exceeds RevPAR in the limited-service and focused-service sectors by 64.7 per cent and 7.7 per cent, respectively.

Table 3 shows a difference in RevPAR of 30.4 per cent between the full-service and the limited-service sectors, and 21.2 per cent between the full-service and the focused-service segments. In this sample, the limitedservice hotels run at a significantly higher occupancy (an average of 83.0 per cent) than either the focused-service hotels (77.0 per cent) or the fullservice hotels (72.0 per cent).

Tables 4 and 5 show sample data from two secondary cities in the USA. In this study, a secondary city is defined as a city with a regional airport.

In secondary cities, the pattern in RevPAR performance appears to be less clear.

Table 4 shows that the limited-service hotels exceed both the focusedservice and the full-service hotels in terms of RevPAR: US $\$ 65$ compared to US $\$ 63$ for both focused-service and full-service hotels. The average

Table 4: Sample data — secondary city, mid-western USA (US\$)

\begin{tabular}{|c|c|c|c|c|c|c|}
\hline \multirow[t]{2}{*}{ Segment } & \multicolumn{2}{|c|}{ Limited service } & \multicolumn{2}{|c|}{ Focused service } & \multicolumn{2}{|c|}{ Full service } \\
\hline & Range & Average & Range & Average & Range & Average \\
\hline Number of rooms & $70-203$ & 122 & $123-149$ & 133 & $213-983$ & 460 \\
\hline Average rate & $78-120$ & 92 & $79-128$ & 99 & $84-126$ & 109 \\
\hline Occupancy (\%) & $64-79$ & 70 & $56-68$ & 63 & $35-76$ & 59 \\
\hline RevPAR & $50-88$ & 65 & $44-84$ & 63 & 44-92 & 63 \\
\hline Largest meeting space $\left(\mathrm{m}^{2}\right)$ & \multicolumn{2}{|l|}{300} & \multicolumn{2}{|l|}{460} & \multicolumn{2}{|l|}{1,400} \\
\hline Location & \multicolumn{2}{|c|}{ Suburban/airport } & \multicolumn{2}{|c|}{ Suburban/airport } & \multicolumn{2}{|c|}{ City centre } \\
\hline F\&B facilities & \multicolumn{2}{|c|}{ Breakfast only } & \multicolumn{2}{|c|}{ Breakfast only } & \multicolumn{2}{|c|}{ Full F\&B services } \\
\hline Condition & \multicolumn{2}{|c|}{ Recent renovation } & \multicolumn{2}{|c|}{$\begin{array}{l}\text { Recent construction or } \\
\text { conversion }\end{array}$} & \multicolumn{2}{|c|}{$\begin{array}{l}\text { Recent or planned/in } \\
\text { progress renovation }\end{array}$} \\
\hline
\end{tabular}

Source: HVS Research

Table 5: Sample data — secondary city, southern USA (US\$)

\begin{tabular}{|c|c|c|c|c|c|c|}
\hline \multirow[t]{2}{*}{ Segment } & \multicolumn{2}{|c|}{ Limited service } & \multicolumn{2}{|c|}{ Focused service } & \multicolumn{2}{|c|}{ Full service } \\
\hline & Range & Average & Range & Average & Range & Average \\
\hline Number of rooms & $115-140$ & 127 & $|3|-223$ & 168 & $290-300$ & 295 \\
\hline Average rate & $117-128$ & 123 & $113-130$ & 120 & $139-147$ & 143 \\
\hline Occupancy \% & $82-93$ & 88 & $77-82$ & 79 & $34-65$ & 49 \\
\hline RevPAR & $96-119$ & 108 & $92-100$ & 95 & $50-90$ & 70 \\
\hline Largest meeting space $\left(\mathrm{m}^{2}\right)$ & \multicolumn{2}{|l|}{60} & \multicolumn{2}{|c|}{120} & \multicolumn{2}{|c|}{1,800} \\
\hline Location & \multicolumn{2}{|c|}{ Urban } & \multicolumn{2}{|c|}{ Suburban/airport } & \multicolumn{2}{|c|}{ Urban, city centre } \\
\hline F\&B facilities & \multicolumn{2}{|c|}{ Breakfast only } & \multicolumn{2}{|c|}{ Breakfast only } & \multicolumn{2}{|c|}{ Full F\&B services } \\
\hline Condition & \multicolumn{2}{|c|}{-} & \multicolumn{2}{|c|}{ Recent conversion } & \multicolumn{2}{|c|}{ Recent renovation } \\
\hline
\end{tabular}

Source: HVS Research 
occupancy of the limited-service hotels is 70 per cent compared to 63 per cent for the focused-service hotels and 59 per cent for the full-service hotels.

Table 5 shows that the limited-service hotels exceed their counterparts markedly in terms of RevPAR: US\$108 compared to US\$95 in the focused-service hotels and US\$70 in the full-service hotels. Although the full-service hotels run at a significantly higher rate (US\$143 compared to US\$123 in the limited-service hotels), the higher occupancy (88 per cent compared to 49 per cent) in the limited-service hotels is sufficient to see the limited-service hotels' RevPAR exceed the full-service hotels' RevPAR by a remarkable 54.3 per cent.

From our review, it appears that in softer markets, where hotels do not have the potential to drive rates significantly, limited-service hotels have the advantage; these properties are able to drive occupancy without sacrificing rate. There are several reasons for this trend.

- Quality and age of the product - many of the limited-service or focused-service brands are newer entries in their respective markets. In the samples analysed, the limited-service and focused-service hotels were all recently constructed or had been recently converted (conversion entailing a complete renovation to adhere to new brand standards). In contrast, renovation work at many of their full-service counterparts, though recent, was more cosmetic, and some fullservice hotels had yet to be renovated.

- Number of rooms - limited-service and focused-service hotels tend to have a lower room count than their full-service counterparts. In the samples surveyed, the limited-service hotels had an average room count of 130, focused-service hotels an average of 181 and the fullservice properties an average of 428 . Hotels with lower room counts are easier to fill and this will often result in a higher occupancy percentage.

- Sales and inventory yield strategy - limited-service and focusedservice hotels are well positioned to use a top-up yield management strategy and rely more on transient demand than on pre-booked groups or allotments at lower rates.

\section{THE EUROPEAN LIMITED-SERVICE MARKET}

Looking at the European market, we see that the situation appears quite different. The European hotel market, with a few exceptions, is not as segmented as hotel markets in the USA. The distinctions between limitedservice, focused-service, extended-stay and full-service hotels are blurred, and it would probably be more realistic to segment the industry by price point (budget, midscale or upscale).

Accor is perhaps the only hotel company that has been able to establish a multisegment profile in the European market (although with a focus on the budget sector of the market), and it has been doing so for many years. A great example of this is Accor's use of the 'cluster' model, that is, having multiple brands present within the same micromarket. Such a 
model does not work in the absence of a multibrand platform. The products must be significantly different from each other to avoid cannibalisation.

A leading hotel brand with a strong presence in the European limitedservice segment is Express by Holiday Inn, which through its aggressive franchising scheme has extended its presence across the continent. $\mathrm{NH}$ Hoteles has introduced a limited-service product with its NH Express brand (15 hotels across Spain). The European hotel market is, however, dominated by hotels in the three-star and four-star categories. The vast majority of these hotels have an all-day dining outlet and some type of meeting space, and could therefore be considered full-service midscale hotels.

Global chains such as Hilton and Marriott International introduced their focused-service brands (such as Hilton Garden Inn and Courtyard by Marriott) to European cities relatively recently. The trend is beginning to change though, as more and more hotel companies are rushing to extend their limited-service and focused-service brands. Marriott International has announced that it has 15 Courtyard by Marriott hotels in the pipeline across Europe; six of them are due to open before the end of 2009. Hilton has announced that it will be opening at least nine new Hilton Garden Inns over the next 24 months, from Bologna, in Italy, to Rzeszów, in Poland. The company has signed a strategic agreement for a total of 15 Hampton Inns and Hilton Garden Inns across Turkey. Express by Holiday Inn, which already has a significant presence in Europe with 176 hotels, has 29 hotels currently under construction across Europe.

\section{LEARNING FROM THE US EXPERIENCE}

So what can be learned from the phenomenon of RevPAR among limitedservice brands exceeding that of their full-service counterparts in more mature markets?

Although the trend is not yet clear in European cities, it may well be an emerging phenomenon, as more and more of these hotels appear on the scene and the market becomes more clearly segmented. Some of the reasons to watch the development of the limited-service and focusedservice brands are as follows:

- More and more non-branded or family-run hotels have been swallowed up by the chains and have been converted to those chains' standards. As a consequence, the typical landscape of a European city market comprises a large portion of full-service hotels in the threestar or four-star category. All of these hotels have at least one all-day restaurant and, often, meeting facilities. Many of these properties are beginning to age, and many are in need not only of renovation but also of structural modernisation (owing to obsolescence). The limitedservice and focused-service hotels are coming onto the market with completely new and modern facilities that are specifically geared to the transient customer (both leisure and business), as many of the large players will only permit new-builds for these brands.

- Central locations are also increasingly difficult to find in cities across Europe. Buildings in city centres are older, sometimes protected, and, 
often, more difficult to renovate for branding/rebranding. In addition, the cost of land in such locations may prohibit hotel development. Limited-service and focused-service products do not necessarily require city-centre locations, but rather peripheral locations near good sources of business and with good access to business parks, airports and so forth. Many of these locations would not necessarily support a full-service product; this would result in poor occupancy. The aforementioned peripheral locations have more easily attainable greenfield or brownfield sites, and the cost of the land is lower.

- With construction costs on the rise in Europe and elsewhere in the world, limited-service and focused-service products are better economic alternatives, making these types of hotel development more accessible to a wider range of hotel investor. With the uncertainty and turbulence in the current debt markets, smaller projects are more likely to benefit from access to debt capital from smaller regional/ domestic banks without specialised hotel mortgage-lending departments.

- In markets where yearly occupancy does not exceed 65 per cent, as is the case in many cities across Europe, a limited-service or a focusedservice property has the advantage of a lower room count and a transient-oriented or top-up yield strategy that gives the potential for higher RevPAR than full-service hotels.

- These brands have the backing of very strong and wide-reaching booking engines, which permit excellent access to transient customers. Such customers generally pay a higher price for a good hotel product than market segments that expect discounts for their volume and early bookings.

\section{THOUGHTS FOR HOTEL INVESTORS}

The European hotel industry is rapidly changing, as can be seen from the numerous announcements in both the trade and the general press of new hotel projects, across a much wider range of brands, product types and segments.

Extended-stay and focused-service hotels, which were, until recently, rather foreign concepts to the European hotel industry, have all of a sudden become more mainstream, which indicates the emergence of a more segmented hotel industry in Europe, with different types of hotels catering to different clients and seeking to meet the specific demands of their specific clients. For hotel investors, this means that an increased amount of choice and scrutiny must become part of the process of seeking out investment opportunities.

This paper looked at three semi-broad segments of the US hotel industry, and identified that the different revenue management strategies associated with the different types of product may have a very interesting bearing on the RevPAR achievements of these three types of hotel under different market conditions. In recent years, the transparency of the European hotel industry has greatly improved, with various benchmark surveys gradually covering more territory. This is likely to further improve with the consolidation of two of these companies into one 
predominant benchmark survey. For hotel investors, this means that market transparency similar to that seen in the USA can be achieved, with investors being able to handpick specific hotels and obtain a one-off historical benchmark survey. With a greater knowledge of how different hotel products use different approaches to revenue management, investors can better analyse market data and make informed opinions about what type of hotel product is likely to result in the highest yield on investment.

Although this paper does not take into account revenues from outlets such as food and beverage, banqueting and meeting rooms, spas and so forth, it should be noted that in many locations such revenue centres may generate strong top-line revenues. Many of these revenue centres also carry great investment costs and/or operational costs with varying flowthrough to the bottom line. Any prudent investor should, however, evaluate all possible investment scenarios in order to achieve the greatest return. As such, we return to the introduction to this paper: tomorrow's hotel investors must seek to identify 'the right asset for the right location'. A better understanding of today's hotel products and how they produce a return for investors is essential.

\section{(C) 2008 HVS}

